\title{
Effects of Forced Hot Air on Zebra Mussel (Dreissena polymorpha) Mortality
}

\section{Background and \\ purpose}

\begin{abstract}
Additional information
\end{abstract}

Approach
It has been over a decade since zebra mussels (Dreissena polymorpha) were first found in benthic samples from Lake St. Clair, Michigan (Herbert, Muncaster, and Mackie 1989). Although chlorine and other chemicals are being used for their control at hydropower stations and other facilities (Miller, Payne, and McMahon 1991; Claudi and Mackie 1994), managers and government officials are encouraging use of alternative, nonchemical methods. Experiments conducted by McMahon, Ussery, and Clarke (1993) were designed to obtain information on the efficacy of dewatering mussel-infested structures. For example, mussels experienced 100 percent mortality when exposed to still air at $25^{\circ} \mathrm{C}$ and 95 percent relative humidity for $96 \mathrm{hr}$. Ricciardi, Serrouya, and Whoriskey (1995) reported similar results at 50 percent relative humidity and temperatures of 20 and $30^{\circ} \mathrm{C}$.

Jenner and Janssen-Mommen (1992) suggested that forcing hot air through dewatered pipes, rather than just exposing them to the atmosphere, should increase mussel mortality. This could greatly reduce the amount of nonoperational time required to kill zebra mussels at a hydropower plant, navigation lock, or other facility.

This technical note reports the results of a laboratory experiment on the use of forced hot air to kill zebra mussels.

This technical note was written by Mr. Thomas A. Ussery, University of Texas at Arlington, and Dr. Andrew C. Miller, U.S. Army Engineer Waterways Experiment Station (WES), Vicksburg, MS. For further information, contact Dr. Miller, (601) 634-2141, millera3@ mail.wes.army.mil.Dr. Ed Theriot, WES, (601) 634-2678, is Manager of the Zebra Mussel Research Program.

Note: The contents of this technical note are not to be used for advertising, publication, or promotional purposes. Citation of trade names does not constitute an official endorsement or approval of the use of such products.

Zebra mussels were allowed to naturally colonize $7.62-\mathrm{cm}$-wide by $61-\mathrm{cm}$-long polyvinyl chloride (PVC) pipes attached to a concrete wall at Black Rock Navigation Lock during the summer and fall of 1994. Pipes were removed on 31 November 1994, packed in coolers with artificial coolant, and shipped to the 
laboratory at the U.S. Army Engineer Waterways Experiment Station in Vicksburg, MS. For each experiment, an infested pipe was attached to a 2-m length of clean pipe that was connected to a standard floor heater with temperature maintained by a Dyna-Sense proportional AC phase controller. A small fan was placed into a PVC pipe coupler near the floor heater. Air speed was measured with a hand-held wind speed indicator (Davis Instruments), and relative humidity and temperature with a Cole-Parmer 3309-60 thermo-hygrometer and Fisher Scientific 15-077-11 digital thermometer.

Two trials were conducted at each of three temperatures $\left(25,35\right.$, and $\left.45^{\circ} \mathrm{C}\right)$. During each trial, six individuals were removed periodically and tested for viability by re-immersing them in dechlorinated tap water for $12 \mathrm{hr}$ at room temperature $\left(22\right.$ to $24^{\circ} \mathrm{C}$ ) and then gently probing the exposed mantle edge with a small brush. The mussel was considered viable if it closed its valves in response to this stimulation. Exposure durations were designed to include 100 percent survival to 100 percent mortality $\left(\mathrm{SM}_{100}\right)$. Because there were no significant mortality differences between trials for each treatment (Student's $t$-test), all data from each temperature were fitted to an equation using least squares linear regression analysis to estimate time for 50 percent mortality $\left(\mathrm{LT}_{50}\right)$.

Forced air speed was maintained at $1.8 \mathrm{~m} / \mathrm{sec}$ for all treatments. Average relative humidity varied from 46.1 percent at $25^{\circ} \mathrm{C}$ to 39.3 percent at $45^{\circ} \mathrm{C}$. Air temperature exiting the test apparatus was always within $2^{\circ} \mathrm{C}$ of that entering it.

Results and Equations from regression analysis for each experimental temperature were sigdiscussion nificant ( $\mathrm{p}<0.05$ ), enabling predictions of $\mathrm{LT}_{50}$ (Table 1 ). At a test temperature of $25^{\circ} \mathrm{C}, \mathrm{LT}_{50}$ using forced air was approximately $10 \mathrm{hr}$ less than with still air, based on studies by McMahon, Ussery, and Clarke (1993). At $35^{\circ} \mathrm{C}$, the $\mathrm{LT}_{50}$ was approximately one third the value obtained by McMahon for still air. Results were the same for all sizes of mussels tested.

\begin{tabular}{|c|c|c|c|c|c|}
\hline \multirow{2}{*}{$\begin{array}{c}\text { Temperature } \\
{ }^{\circ} \mathbf{C}\end{array}$} & \multirow[b]{2}{*}{ Still Air LT $\mathbf{L}_{50}$} & \multicolumn{4}{|c|}{ Forced Air } \\
\hline & & SM100 & $\mathbf{R}^{2}$ & $\mathbf{P}$ & LTs0 \\
\hline $\begin{array}{l}25 \\
35 \\
45\end{array}$ & $\begin{array}{l}43 \\
16 \\
\text { Not determined }\end{array}$ & $\begin{array}{r}49.0 \\
11.0 \\
2.5\end{array}$ & $\begin{array}{l}0.79 \\
0.66 \\
0.95\end{array}$ & $\begin{array}{l}<0.00001 \\
<0.00131 \\
<0.00408\end{array}$ & $\begin{array}{r}32.7 \\
4.6 \\
1.4\end{array}$ \\
\hline
\end{tabular}

Studies by McMahon, Ussery, and Clarke (1993) and Ricciardi, Serrouya, and Whoriskey (1995) demonstrated that exposing components of facilities to warm still air would be an efficient and cost-effective way to control zebra mussel infestations. As suggested by Jenner and Janssen-Mommen (1992) and Claudi and Mackie (1994), the present study indicated that forced hot air could greatly reduce the amount of nonoperational time required to mitigate zebra mussel infestations. Alternatively, individual components could be dewatered and treated separately. Hot air is easily and inexpensively generated, and the associated environmental impacts from discharge are usually negligible. 
References Claudi, R., and Mackie, G. L. (1994). Practical manual for zebra mussel monitoring and control. CRC Press, Inc., Boca Raton, FL.

Herbert, P. D. N., Muncaster, B. W., and Mackie, G. L. (1989). "Ecological and genetic studies on Dreissena polymorpha (Pallas): A new mollusc in the Great Lakes," Canadian Journal of Fisheries and Aquatic Sciences 46, 158791.

Jenner, H. A., and Janssen-Mommen, J. P. M. (1992). "Monitoring and control of Dreissena polymorpha in industrial and power plant cooling water systems." Zebra mussels: Biology, impacts and controls. T. F. Nalepa and D. W.

Schoesser, ed., Lewis Publishers, Boca Raton, FL, 537-54.

McMahon, R. F., Ussery, T. A., and Clarke, M. (1993). "Use of emersion as a zebra mussel control method," Contract Report EL-93-1, U.S. Army Engineer Waterways Experiment Station, Vicksburg, MS.

Miller, A. C., Payne, B. S., and McMahon, R. F. (1991). "Control strategies suitable for zebra mussel infestations at public facilities." Proceedings, 1991 Zebra Mussel Control Technology Conference, Chicago, IL, sponsored by Electric Power Research Institute, Palo Alto, CA, 1-19 - 1-30.

Ricciardi, A., Serrouya, R., and Whoriskey, F. G. (1995). "Aerial exposure tolerance of zebra and quagga mussels (Bivalvia: Dreissenidae): Implications for overland dispersal," Canadian Journal of Fisheries and Aquatic Sciences 52, 470-77. 